\title{
Comparative analysis on bioactive compounds and antioxidant activity of Algerian fenugreek (Trigonella foenum-graecum L.) and Syrian cumin (Cuminum cyminum L.) seeds
}

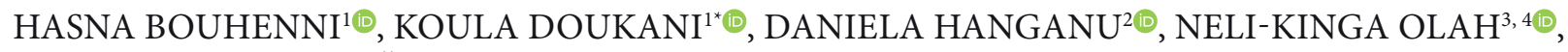 \\ NAZIM ŞEKEROĞLU ${ }^{\circledR}$, SEVGI GEZICI ${ }^{6}{ }^{\oplus}$, MARINA SPINU $^{7}$, MIHAELA NICULAE $^{7}$
}

\begin{abstract}
${ }^{1}$ Department of Nature and Life Sciences
Faculty of Nature and Life Sciences

University of Tiaret, Algeria

${ }^{2}$ Department of Pharmacognosy, Faculty of Pharmacy Iuliu Hatieganu University of Medicine and Pharmacy Cluj-Napoca, Romania
\end{abstract}

${ }^{3}$ Faculty of Pharmacy

Vasile Goldi Western University of Arad

Arad, Romania

${ }^{4}$ SC PlantExtrakt SRL

Radaia, Cluj, Romania

${ }^{5}$ Department of Horticulture

Faculty of Agriculture

Kilis 7 Aralik University

79000 Kilis, Turkey

${ }^{6}$ Department of Molecular Biology and Genetics

Faculty of Arts and Sciences

Kilis 7 Aralık University

79000 Kilis, Turkey

${ }^{7}$ Department of Infectious Diseases, Clinical Sciences

University of Agricultural Sciences and Veterinary Medicine

Cluj-Napoca, Romania

*corresponding author: e-mail: k_doukani@univ-tiaret.dz 


\section{Summary}

Introduction: Natural products represent a gold mine for scientists looking for compounds for the treatment of health problems and diseases with their different biological and pharmacological activities. However, recent research is focused on finding natural sources of antioxidants.

Objective: The objective of current research was to determine the phytochemical profile of Algerian fenugreek (Trigonella foenum-graecum L.), and Syrian cumin (Cuminum cyminum L.) seeds in order to characterize their phenolic compounds and to determine their antioxidant activities.

Methods: Total phenolic, flavonoids, condensed and hydrolysable tannins contents were quantified using Folin-Ciocalteu, aluminium chloride, vanillin and ferric chloride methods, respectively. Phenolic compounds were identified by HPLC method and antioxidant activity was measured using DPPH assay.

Results: The higher amounts of total phenolic compounds, flavonoids, condensed and hydrolysable tannins were given by fenugreek. Results of HPLC analysis of our plants showed that eight phytochemical compounds were found in cumin extract, and seven molecules in fenugreek extract. Moreover, fenugreek possessed higher antioxidant activity.

Conclusion: This study confirmed that our plants are a good source of phenolic contents and possess a high antioxidant activity.

Key words: Trigonella foenum-graecum L., Cuminum cyminum L., phytochemistry, HPLC, DPPH

Słowa kluczowe: Trigonella foenum-graecum L., Cuminum cyminum L., fitochemia, HPLC, DPPH

\section{INTRODUCTION}

The aetiology of a variety of diseases, including some types of cancer, atherosclerosis, cardiovascular diseases, neurodegenerative diseases, infections, chronic inflammatory diseases, diabetes and autoimmune diseases, has been highly affected by increased levels of free radicals and subsequent oxidative stress [1]. In order to treat problems of oxidative stress, researchers interest in plants which are important source of natural antioxidants (phenolic compounds, flavonoids and vitamins) [2]. Most of plants have ethnomedical practises known to present numerous medicinal properties in their extract [3], as well as antioxidant, antimicrobial, hypolipidemic, anti-inflammatory, anticancer, central nervous system, cardiovascular, analgesic, antipyretic, immunological, and many other pharmacological activities [4].

Cumin (Cuminum cyminum L.) is an essential seed spice used by humankind and one of the oldest known minor spices. It originates from Syria, Egypt, Turkey and Eastern Mediterranean area [5]. In several studies antidiabetic [6], antifungal [7], antibacterial [8], antioxidant [9], bronchodilatory [10], hepatoprotective and renoprotective [11], chemopreventive [12], antiepileptic [13], galactagogue [14], hypolipidemic [6], male antifertility [15], memoryenhancing and antistress [16] effect of C. cyminum seed extracts have been reported. Cumin contains numerous phytochemical effects that have several biological activities, such as antimicrobial, insecticidal and antioxidant [17].

Fenugreek (Trigonella foenum-graecum L.) is one of the oldest Fabaceae family of medicinal plants native to central Asia, with exceptional medicinal and nutritional profile [18]. Fenugreek seeds possess wide range of properties, particularly bitter taste, aromatic smell, carminative characteristics, antibacterial and antioxidant effects [19]. Therefore, they are used as a common remedy in Indian and Chinese medicines for the treatment of diabetes and hypercholesterolaemia [20]. It has been stated that it has restorative and nutritional properties and stimulates digestive processes which are useful in healing various digestive tract ulcers [21]. Pharmacological characteristics such as antitumour, antiviral, antimicrobial, anti-inflammatory, hypotensive and antioxidant have been also recorded for fenugreek [22]. Phenolic acids, such as vanillic acid, coumaric acid, ferulic acid and gallic acid, are present in fenugreek seeds. There is a stronger antioxidant potential for these acids [23, 24].

The beneficial health effects of these two plants prompted us to investigate their secondary metabolites in order to provide important information on their chemical content and their pharmacological effects. Although, the goal of this paper was to determine and quantify the phenolic contents of fenugreek (Trigonella foenum-graecum L.), and cumin (Cuminum cyminum L.) seeds by HPLC method, and to investigate their antioxidant activity. 
Our study is the first report on polyphenolic composition of methanolic extract of Algerian fenugreek and Syrian cumin.

\section{MATERIAL AND METHODS}

\section{Sample preparation}

According to Bouhenni et al. [25], Algerian variety of fenugreek (Trigonella foenum-graecum L.) and Syrian cumin (Cuminum cyminum L.) were the best ones, as compared to other varieties with a highest weight and a better germination rate. In this concept, these varieties were chosen for present study. Fenugreek seeds were grown in the region of Mostaganem, Algeria, and cumin seeds were grown in the region of Aleppo, Syria.

Samples of fenugreek and cumin were taken from a local market in Algeria in March 2017 in order to avoid the dust, the loss of aroma and colour which could occur as a result of their exposure to the direct sun light. They were sorted, washed, and dried at a room temperature then ground and screened at $200 \mu \mathrm{m}$ using electrical grinder. Resultant powders were analysed for their chemical and biological aspects.

\section{Phytochemical analysis of fenugreek and cu- min samples}

\section{Preparation of extracts}

The extracts were prepared using maceration method, all the extraction procedures and conditions were performed as described by Gezici et al. [26]. $100 \mathrm{ml}$ of $70 \%$ methanol was mixed with $10 \mathrm{~g}$ of each sample, the solutions were shaken at a room temperature for $24 \mathrm{~h}$, then the mixtures were filtered using Whatman paper $\mathrm{N}^{\circ} 01$ and evaporated using rotary evaporator. Dried extract was conserved in the refrigerator at $4^{\circ} \mathrm{C}$ for further analyses. Each extract was dissolved at $1 \mathrm{mg} / \mathrm{ml}$. Finally, yield extraction $(w / w \%)$ was determined.

\section{Phytochemical tests}

\section{- Determination of total phenolic content}

Total phenolic content was estimated according to the procedure described by Singleton et al. [27] using Folin-Ciocalteu reagent. $0.5 \mathrm{ml}$ of different concentrations of each extract and $2.5 \mathrm{ml}$ of FolinCiocalteu were mixed with $1 \mathrm{ml}$ of sodium carbonate $(20 \%)$. This mixture was incubated for $30 \mathrm{~min}$. in the dark at a room temperature. The absorption of the solution using the UV-Vis spectrophotometer was measured at $765 \mathrm{~nm}$. A calibration curve was established using gallic acid as standard. The results were expressed as milligram of gallic acid equivalent (GAE) per $100 \mathrm{~g}$ of dry matter.

\section{- Determination of total flavonoids content}

Total flavonoids content of both extracts was determined using aluminium chloride method [28]. $1.5 \mathrm{ml}$ of different concentrations of all extracts was mixed with $75 \mu \mathrm{l}$ of aluminium chloride solution and $0.5 \mathrm{ml}$ of sodium acetate solution. The mixture was completed with distilled water until it reached a volume of $2.5 \mathrm{ml}$. Using a UV-Vis spectrophotometer, the absorption of the solution was measured at $415 \mathrm{~nm}$ after the incubation time of $30 \mathrm{~min}$. at a room temperature in the dark. The results were expressed as milligram of quercitin equivalent (QE) per $100 \mathrm{~g}$ of dry matter through a calibration curve.

\section{- Determination of condensed tannins content}

Condensed tannins content was estimated using the method of Price [29]. $1 \mathrm{ml}$ of each extract was added to $2.5 \mathrm{ml}$ of $4 \%$ methanol vanillin solution and $2.5 \mathrm{ml}$ of $\mathrm{H}_{2} \mathrm{SO}_{4}$. The absorbance was measured at $500 \mathrm{~nm}$ after $15 \mathrm{~min}$. The results were expressed as milligram of catechin equivalent (CE) per $100 \mathrm{~g}$ of dry matter via a calibration curve.

\section{- Determination of hydrolysable tannins content}

Hydrolysable tannins content was estimated according to the method of Mole [30]. $500 \mu \mathrm{l}$ of the extract was mixed with $3.5 \mathrm{ml}$ of the ferric chloride solution. After $15 \mathrm{~s}$, the absorbance was measured at $660 \mathrm{~nm}$. The results were expressed as milligram of tannic acid equivalent (TAE) per $100 \mathrm{~g}$ of dry matter via a calibration curve.

\section{Phytochemical screening}

Qualitative tests were realized in order to identify the presence of some phytochemical compounds in plants extracts according to Trease and Evans [31] and Sofowora [32], as shown in table 1. 
Table 1.

Phytochemical screening tests

\begin{tabular}{lll}
\hline \multicolumn{1}{c}{ Metabolites } & \multicolumn{1}{c}{ Added reagent } & \multicolumn{1}{c}{ Expected result } \\
\hline Flavonoids & $\mathrm{KOH}(50 \%)$ & yellow color \\
\hline Tannins & $\mathrm{FeCl}_{3}(1 \%)$ & blue coloration \\
\hline Alkaloids & $\mathrm{HCl} 2 \%+$ Wagner reagent & brown precipitate \\
\hline Sterols and triterpenes & acetic anhydride $+\mathrm{H}_{2} \mathrm{SO}_{4}(98 \%)$ & $\begin{array}{l}\text { red colour (surface) }+ \\
\text { greenish fluorescence }\end{array}$ \\
\hline Terpenoids & chloroform $+\mathrm{H}_{2} \mathrm{SO}_{4}(98 \%)$ & reddish brown coloration \\
\hline Saponins & distilled water & formation of foam \\
\hline Anthocyanins & chlorhydric alcohol + isoamyl alcohol & $\begin{array}{l}\text { reddish brown } \\
\text { coloration }\end{array}$ \\
\hline Cardiac glycosides & glacial acetic acid $+\mathrm{FeCl}_{3}(5 \%)+\mathrm{H}_{2} \mathrm{SO}_{4}(98 \%)$ & brown ring \\
\hline Reducing compounds & Fehlings $(\mathrm{A}+\mathrm{B})$ & brownish-red precipitate
\end{tabular}

\section{Chromatographic analysis (HPLC)}

Phytochemical compounds were identified using high-performance liquid chromatography (HPLC). According to their polarity in the solvents, the model of HPLC used was Shimadzu Nexera-I HPLC with autosampler and quaternary pump. Each extract was dissolved in methanol in a ratio of 1 part of extract to 5 parts of solvent. The extracts were analysed as such by injection into HPLC. The operating conditions are as follows: column: silica gel-C18 type Fortis C18, 150 × $2.1 \mathrm{~mm} \times 3 \mu \mathrm{m}$, eluent: A - water, $\mathrm{B}-0.1 \%$ formic acid, aqueous solution with $\mathrm{pH}=2.5$, and $\mathrm{C}-$ acetonitrile, flow rate: $1 \mathrm{ml} / \mathrm{min}$., injected volume: $5 \mu$ l, detector: $\mathrm{DAD}$, spectrophotometric $220-400 \mathrm{~nm}$, with chromatograms recorded at 254, 326 and $360 \mathrm{~nm}$. The evaluation was based on a comparison of retention times and absorption maxima in the UV-Vis spectra.

In comparison with standards (standard pure phytochemical molecules), the resulting chromatographic profile is injected under the same operating conditions as that of the sample. The integrator determines the retention time (Rt) of each component by giving a peak on the chromatogram [33].

\section{Antioxidant activity}

The antioxidant power of plants extracts was evaluated by Shimada et al. [34] using the DPPH method. The DPPH solution $(0.1 \mathrm{mM})$ was obtained by dissolving $4 \mathrm{mg}$ DPPH in $100 \mathrm{ml}$ methanol.
Serial dilution was prepared in order to obtain all increasing concentration required $(0.1,0.2,0.3,0.4$, $0.5 \mathrm{mg} / \mathrm{ml}$ ). The solutions were then incubated at room temperature in the dark for $30 \mathrm{~min}$., and the absorbance was measured at $570 \mathrm{~nm}$. The antioxidant activity was determined using the following formula:

$$
\% \text { inhibition }=\frac{A_{\text {control }}-A_{\text {sample }}}{A_{\text {control }}} \times 100,
$$

where

$\mathrm{A}_{\text {control }}$ - absorbance of DPPH solution without extract,

$\mathrm{A}_{\text {sample }}$ - absorbance of sample with DPPH solution.

The half-maximal inhibitory concentration $\left(\mathrm{IC}_{50}\right)$ was defined as the amount of antioxidant needed to decrease the initial DPPH concentration by $50 \%$.

\section{Statistical analysis}

Statistical software program (SPSS version 20) was used to analyse our obtained results. The differences between the means were considered significant for $p$ values lower than 0.05 . Results were expressed as mean values and standard deviation with three repetitions.

Ethical approval: The conducted research is not related to either human or animal use. 


\section{RESULTS}

\section{Phytochemical analysis}

The results of yield extraction, total phenolic, total flavonoid, condensed and hydrolysable tannins content in fenugreek and cumin extracts are presented in table 2.

\section{Table 2.}

Results of yield extraction, total phenolic, total flavonoid, condensed and hydrolysable tannins content of fenugreek and cumin

\begin{tabular}{lcc}
\hline \multicolumn{1}{c}{ Analysis } & Fenugreek extract & Cumin extract \\
\hline Yield extract $(\%)$ & $17.66 \pm 0.033$ & $14.29 \pm 0.002$ \\
\hline $\begin{array}{l}\text { TPC } \\
(\mathrm{mg} \mathrm{GAE} / 100 \mathrm{~g} \mathrm{DM})\end{array}$ & $115.3 \pm 0.01$ & $91.6 \pm 0.001$ \\
\hline $\begin{array}{l}\text { TFC } \\
(\mathrm{mg} \mathrm{QE} / 100 \mathrm{~g} \mathrm{DM})\end{array}$ & $80.98 \pm 0.066$ & $66.04 \pm 0.15$ \\
\hline $\mathrm{CTC}$ & $2.2 \pm 0.01$ & $1.8 \pm 0.033$ \\
$(\mathrm{mg} \mathrm{CE} / 100 \mathrm{~g} \mathrm{DM})$ & $1 \pm 0.045$ & $0.205 \pm 0.001$ \\
\hline $\begin{array}{l}\text { HTC } \\
(\mathrm{mg} \text { TAE} / 100 \mathrm{~g} \mathrm{DM})\end{array}$ & & \\
\hline
\end{tabular}

TPC - total phenolic content; TFC - total flavonoids content; CTC - condensed tannins content; HTC - hydrolysable tannins content; DM - dry matter

The obtained results showed that the yield extract of fenugreek using maceration method and $70 \%$ methanol as solvent was higher $(17.66 \pm 0.033 \%)$ than that of cumin $(14.29 \pm 0.002 \%)$.

In the present study, the results showed that cumin extract expresses the higher phenolic content $(115.3 \pm 0.01 \mathrm{mg}$ GAE/100 g DM) than fenugreek extract $(91.6 \pm 0.001 \mathrm{mg}$ GAE/100 g DM). Also for total flavonoid, the highest content was given by fenugreek extract $(80.98 \pm 0.066 \mathrm{mg}$ QE/100 g DM), as compared to cumin extract (66.04 $\pm 0.15 \mathrm{mg} \mathrm{QE} / 100 \mathrm{~g} \mathrm{DM})$. Also fenugreek showed the higher value of condensed tannins (2.2 $\pm 0.01 \mathrm{mg} \mathrm{CE} / 100 \mathrm{~g} \mathrm{DM})$ in comparison with cumin $(1.8 \pm 0.033 \mathrm{mg} \mathrm{CE} / 100 \mathrm{~g} \mathrm{DM})$.

The results of qualitative assay of samples were shown in table 3 . The results revealed the presence of flavonoids, tannins, terpenoids, anthocyanins and cardiac glycosides both in fenugreek and cumin extracts, with moderate difference. On the other hand, reducing compounds, alkaloids, sterols, triterpenes and saponosides were absent in the tested extracts.

Table 3.

Results of phytochemical screening of fenugreek and cumin

\begin{tabular}{lcc}
\hline \multicolumn{1}{c}{ Analysis } & $\begin{array}{c}\text { Fenugreek } \\
\text { extract }\end{array}$ & $\begin{array}{c}\text { Cumin } \\
\text { extract }\end{array}$ \\
\hline Flavonoids & ++ & +++ \\
\hline Tannins & ++ & +++ \\
\hline Alkaloids & - & - \\
\hline Sterols and triterpenes & - & - \\
\hline Terpenoids & ++ & +++ \\
\hline Saponosids & - & - \\
\hline Anthocyanins & + & ++ \\
\hline Cardiac glycosides & ++ & +++ \\
\hline Reducing compounds & - & - \\
\hline
\end{tabular}

$(-)$ : absent; $(+)$ : low presence; $(++)$ : medium presence; $(+++)$ : high presence

\section{Chromatographic analysis HPLC}

The molecular separation of fenugreek and cumin methanolic extracts was achieved by HPLC at three wavelengths: $254 \mathrm{~nm}, 326 \mathrm{~nm}$ and $360 \mathrm{~nm}$. The findings obtained are visible in the peaks and retention time of chromatograms of each molecule. The results obtained are shown in the chromatograms with peaks and retention time of each molecule (fig. 1-6).

The results of HPLC showed the presence of fifteen compounds in C. cyminum extract (fig. 1-3) and eight compounds in T. foenum-graecum (fig. 4-6), which were identified by comparison between their retention times (Rt) with that of pure standards under the same experimental conditions.

Molecules identified in the methanolic extracts of C. cyminum and T. foenum-graecum are mentioned in table 4.

Eight phytochemical compounds could be identified in C. cyminum extract, namely: caffeic acid, isoquercetin, vanillic acid, myricetin $3-0$, rutinoside, syringaresinol, citrusine, rosmarinic acid, $p$-coumaric acid. Seven compounds of $T$. foenumgraecum extract are: gallic acid, sinapic acid, caffeic acid, asterogenic acid, pyrogallol, hyperoside and ferulic acid. Other molecules could not be identified. 


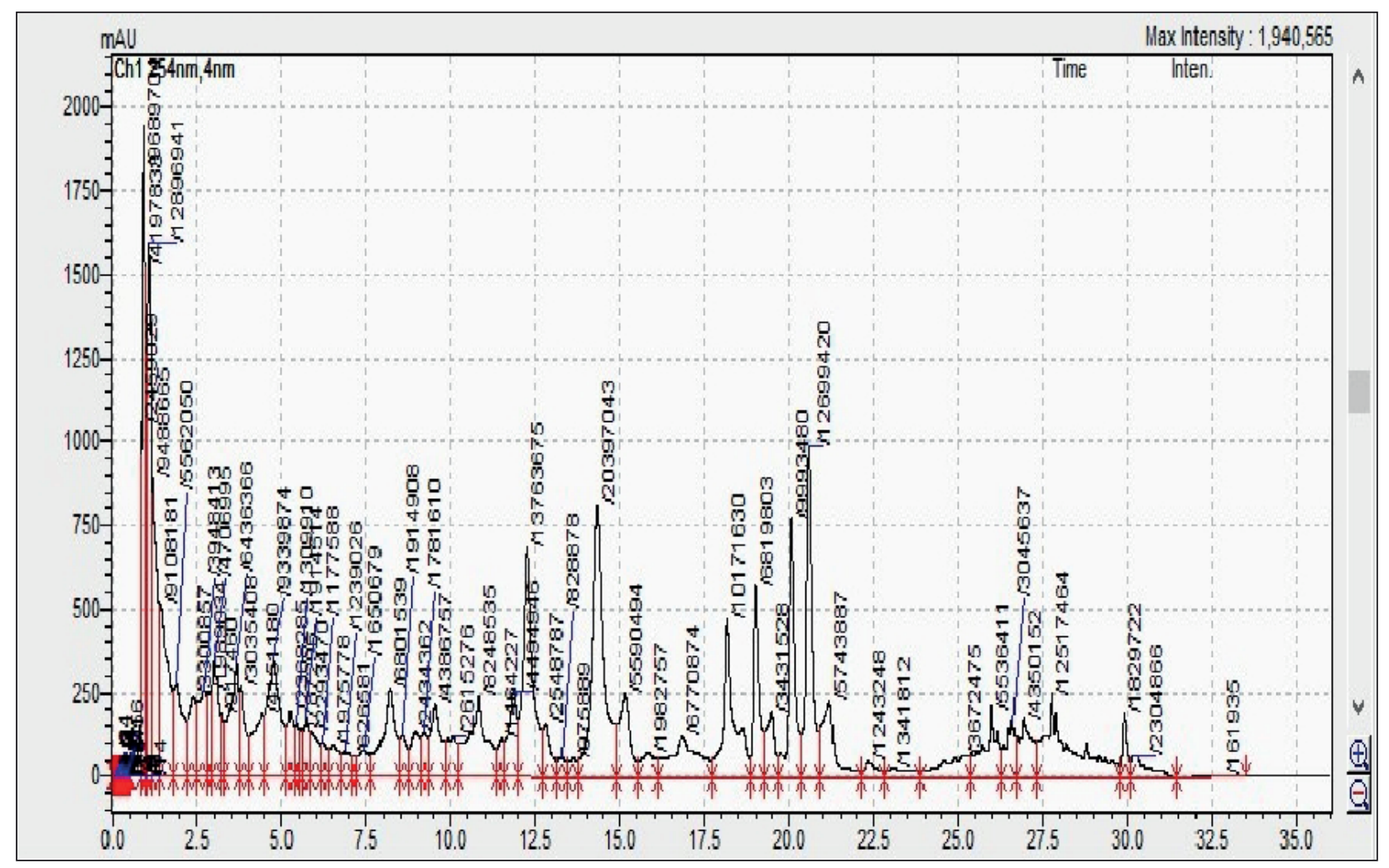

Figure 1.

HPLC chromatogram of Cuminum cyminum dry extract at $254 \mathrm{~nm}$

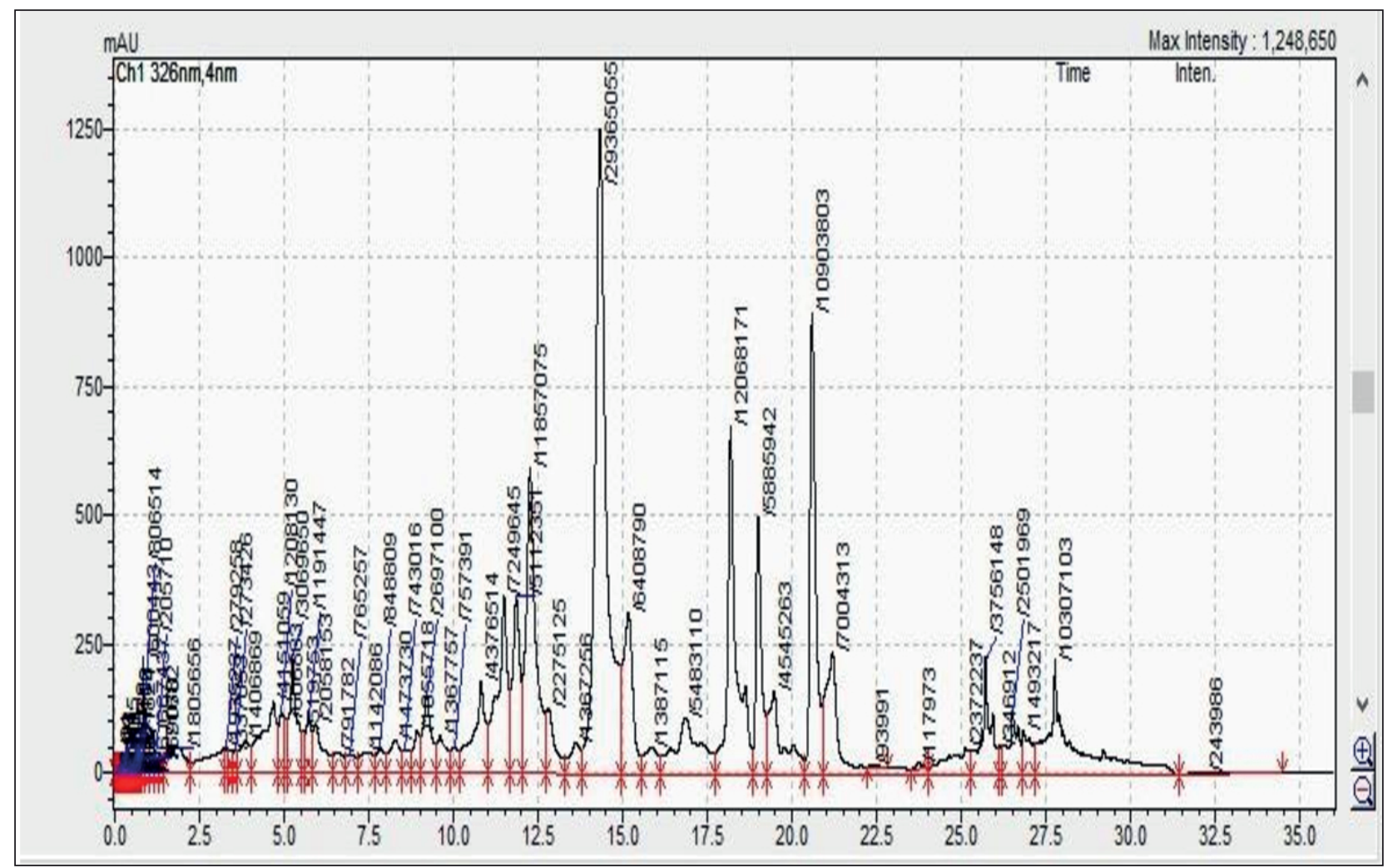

Figure 2.

HPLC chromatogram of Cuminum cyminum dry extract at $326 \mathrm{~nm}$ 


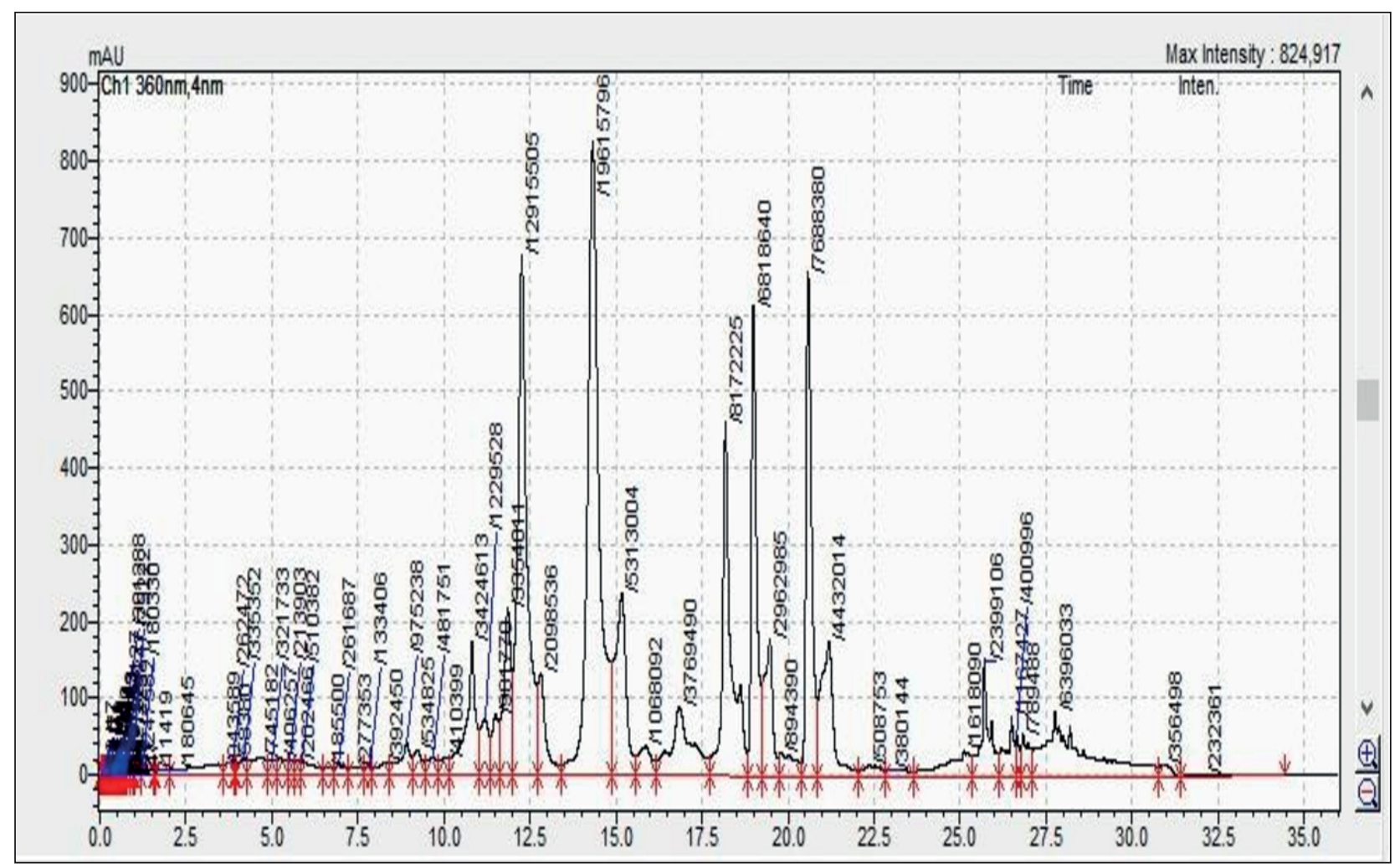

Figure 3.

HPLC chromatogram of the Cuminum cyminum dry extract at $360 \mathrm{~nm}$

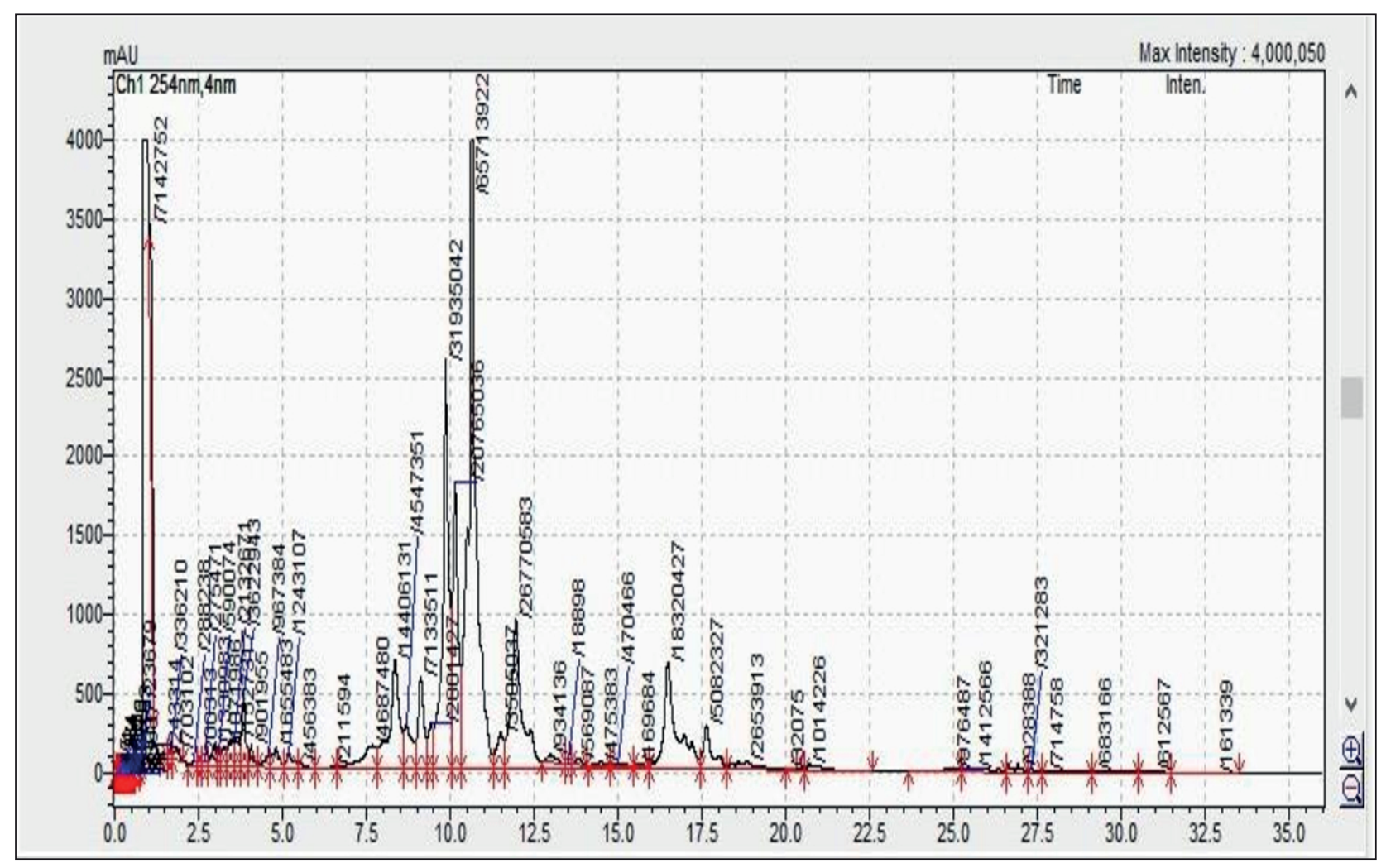

Figure 4.

HPLC chromatogram of Trigonella foenum-graecum dry extract at $254 \mathrm{~nm}$ 


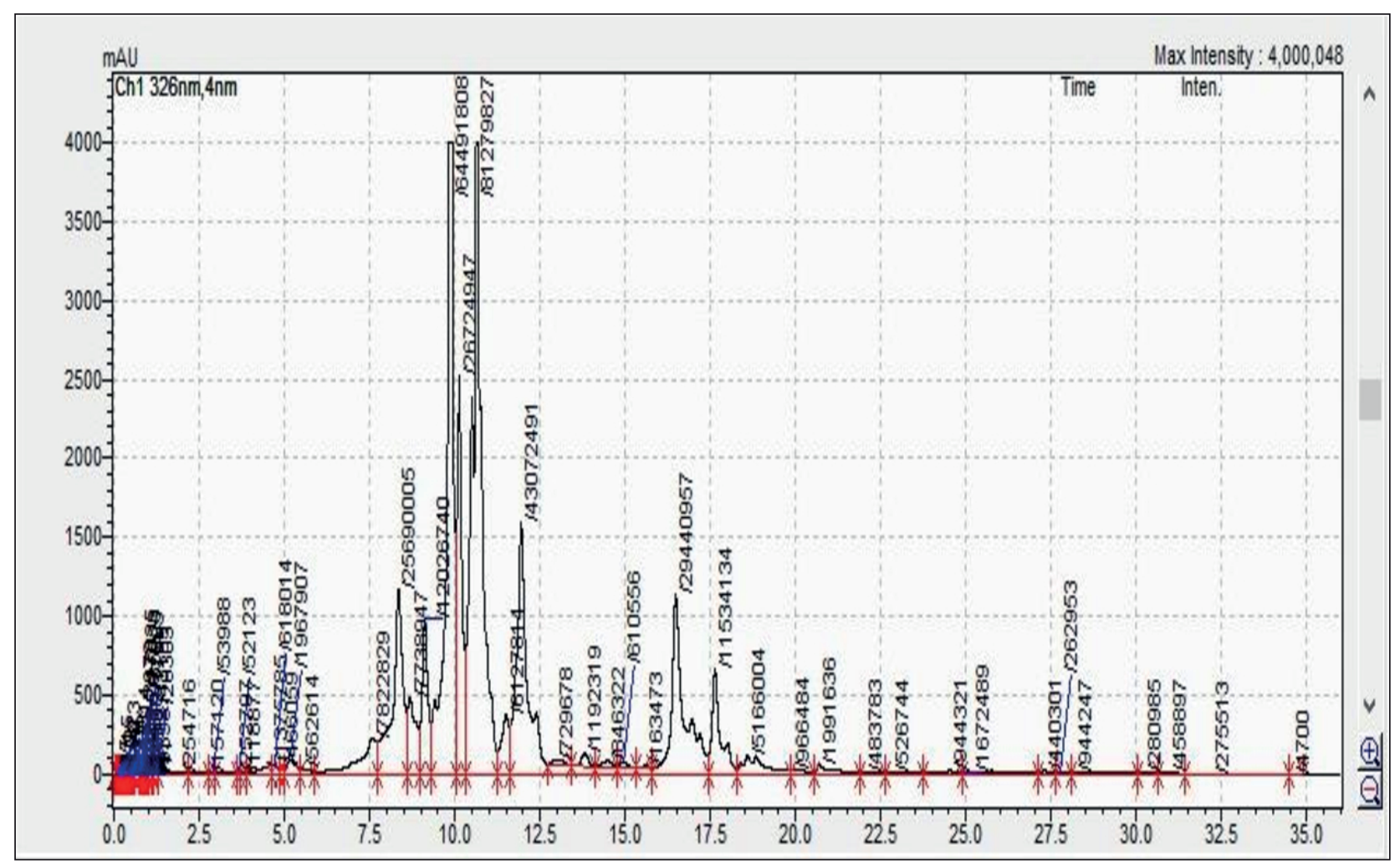

Figure 5.

HPLC chromatogram of Trigonella foenum-graecum dry extract at $326 \mathrm{~nm}$

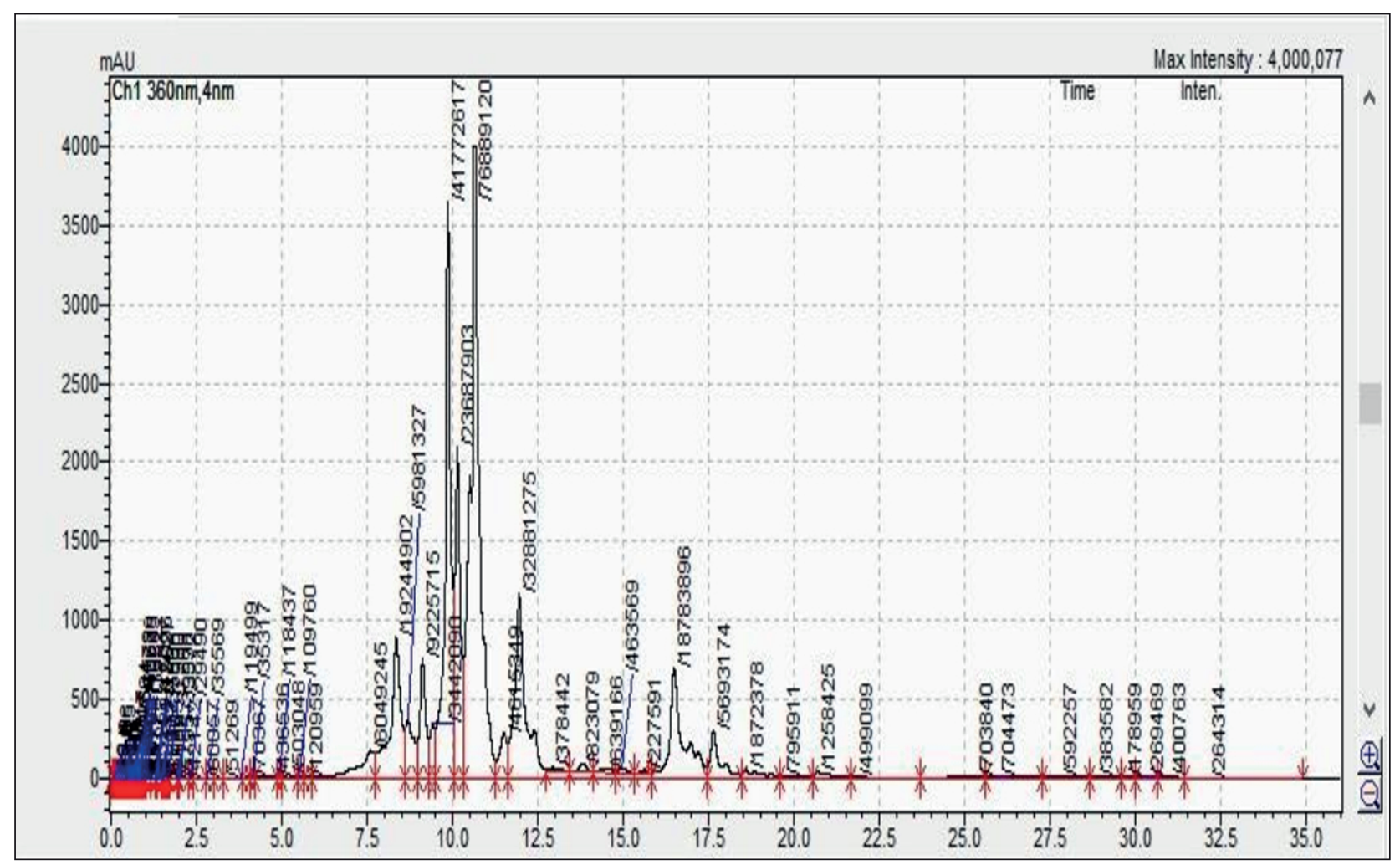

Figure 6.

HPLC chromatogram of Trigonella foenum-graecum dry extract at $360 \mathrm{~nm}$ 
Table 4.

Polyphenolic compounds of fenugreek and cumin analyzed by HPLC

\begin{tabular}{|c|c|c|}
\hline Extract & Compounds & $\begin{array}{l}\text { Retention time } \\
{[\mathrm{min}]}\end{array}$ \\
\hline \multirow{15}{*}{$\begin{array}{l}\text { Cuminum } \\
\text { cyminum }\end{array}$} & l & 4.684 \\
\hline & / & 7.881 \\
\hline & l & 10.812 \\
\hline & caffeic acid & 12.280 \\
\hline & / & 14.322 \\
\hline & isoquercetin & 15.165 \\
\hline & l & 15.857 \\
\hline & vanillic acid & 15.835 \\
\hline & l & 18.179 \\
\hline & syringaresinol & 19.007 \\
\hline & / & 19.487 \\
\hline & myricetin $3-0$ pentoside & 20.030 \\
\hline & citrusine & 20.602 \\
\hline & rosmarinic acid & 21.197 \\
\hline & $p$-coumaric acid & 25.719 \\
\hline \multirow{8}{*}{$\begin{array}{l}\text { Trigonella } \\
\text { foenum- } \\
\text { graecum }\end{array}$} & gallic acid & 3.115 \\
\hline & sinapic acid & 7.577 \\
\hline & caffeic acid & 9.838 \\
\hline & asterogenic acid & 10.146 \\
\hline & 1 & 10.657 \\
\hline & pyrogallol & 11.957 \\
\hline & hyperoside & 16.480 \\
\hline & ferulic acid & 17.647 \\
\hline
\end{tabular}

Table 5.

Results of antioxidant activity of fenugreek and cumin

\begin{tabular}{cccc}
\hline Extract & $\begin{array}{c}\text { Extract concentration } \\
{[\mu \mathrm{g} / \mathrm{ml}]}\end{array}$ & $\begin{array}{c}{[\%]} \\
\text { Inhibition }\end{array}$ & $\begin{array}{c}\mathrm{IC}_{50} \\
{[\mu \mathrm{g} / \mathrm{ml}]}\end{array}$ \\
\cline { 1 - 3 } & 1000 & 82.57 & \\
\cline { 2 - 3 } $\begin{array}{c}\text { Methanolic } \\
\text { extract of } \\
\text { fenugreek }\end{array}$ & 500 & 80.59 & \\
\cline { 2 - 3 } & 250 & 39.20 & \\
\cline { 2 - 3 } & 125 & 35.84 & \\
\cline { 2 - 3 } $\begin{array}{c}\text { Methanolic } \\
\text { extract of } \\
\text { cumin }\end{array}$ & 1000 & 68.51 & \\
\cline { 2 - 3 } & 500 & 55.04 & \\
\hline
\end{tabular}

\section{Antioxidant activity}

The results of the antioxidant power of plants extracts carried out by DPPH method were presented in table 5. They showed that methanolic extract of fenugreek had the strongest radical-scavenging effect, as compared to cumin methanolic extract.

\section{DISCUSSION}

The result of percentage yield of fenugreek extract was approximately similar to the result of Abdouli

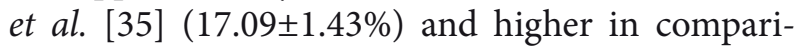
son with the result of Sakhira et al. [36] which was $4.95 \%$. Although, the percentage yield of cumin extract was higher than that of the earlier research of Megha [37] with an amount of $15.93 \%$, and extremely higher than the result of Elghorab et al. [38] which was $4.08 \pm 0.17 \%$. Thippeswamy and Naidu [39] observed that high yield extract was given with methanol solvent. Significant differences were observed among yields extraction between fenugreek and cumin $(p=0.000)$.

The chemical composition of phytochemicals, the extraction method used, the particle size of the sample, the solvent used, as well as the presence of interfering substances affect the extraction yield [40].

This latter depends on the solvent with different polarities, extraction time, $\mathrm{pH}$, temperature, and composition of the sample solvent as well as on the composition of sample. These are known as the most significant parameters under the same extraction time and temperature [41].

Similarly, this difference may be due to a greater solubility in methanol than in other solvents of extractable bioactive components such as carbohydrates and proteins [42].

The difference in extracted yields may be due to the difference in solvent polarities used, which also plays a key role in the increasing phytochemical compound solubility $[42,43]$.

Variations in the structure of phytochemical molecules also determine their solubility in solvents with different polarities [44].

Total phenolic contents of fenugreek were significantly lower than those found by Kaviarasan et al. [36, 45-48] with values of $480 \mathrm{mg}$ GAE/100 g, 589 $\pm 0.02 \mathrm{mg} \mathrm{GAE} / 100 \mathrm{~g}, 1260 \mathrm{mg}$ GAE/100 g, $2300 \mathrm{mg} \mathrm{GAE} / 100 \mathrm{~g}$ and $5430 \mathrm{mg}$ GAE/100 g, respectively. However, result of Benziane et al. [49] study on aqueous extract of fenugreek was extremely lower than present result: $18.9 \mathrm{mg}$ GAE/100 g. While many studies have been carried out to estimate the amount of total phenolic contents in cumin, they gave a higher results than ours: Shan et al. [50], [17, 38, 39, 51-55] with 
an amount of $230 \mathrm{mg}$ GAE/100 g, 333-431 mg GAE/100 g, $685 \mathrm{mg} \mathrm{GAE} / 100 \mathrm{~g}, 900 \mathrm{mg} \mathrm{GAE} / 100 \mathrm{~g}$, $1832 \pm 0.23 \mathrm{mg} \mathrm{GAE} / 100 \mathrm{~g}, 1920 \mathrm{mg}$ GAE$/ 100 \mathrm{~g}$, $2466 \mathrm{mg} \mathrm{GAE} / 100 \mathrm{~g}, 2950 \pm 0.58 \mathrm{mg} \mathrm{GAE} / 100 \mathrm{~g}$ and $3530 \mathrm{mg}$ GAE/100 g, respectively.

The difference in phenolic composition between fenugreek and cumin $(p=0.000)$ could be due to extraction method, plant organ, type of cultivar, harvest time, storage conditions, and genetic or geographical origin [56].

The season and sunlight duration are also known to affect the plant metabolism, since some compounds may be accumulated at a particular time to respond to environmental changes [57].

Several studies have also shown that solvent polarity contributes to substantially different phenolic compound extraction capacities in plants $[58,59]$.

The higher phenolic acid levels in methanolic extracts could be due to extraction of both non polar and semi polar soluble phenolic acids [39].

Total flavonoids analysis expressed that the amount of total flavonoids contents in fenugreek was higher than the amounts found by Abdouli et al. $[35,46,60]$ which were $0.77 \mathrm{mg} \mathrm{QE} / 100 \mathrm{~g}, 31.8 \mathrm{mg}$ $\mathrm{QE} / 100 \mathrm{~g}$ and $20.8-65.3 \mathrm{mg} \mathrm{QE} / 100 \mathrm{~g}$, respectively. However, Sakhira et al. $[36,61,62]$ revealed a raised amount: 136 to $274 \mathrm{mg} \mathrm{QE} / 100 \mathrm{~g}, 145 \mathrm{mg}$ QE/100 g, $377.8 \mathrm{mg} \mathrm{QE} / 100 \mathrm{~g}$ and $4990 \mathrm{mg} / 100 \mathrm{~g} \mathrm{OE}$, respectively. Regarding cumin, significant differences in total flavonoids contents were remarked relatively to previous study of Rebey et al. [51] with a value of $56 \mathrm{mg}$ QE/100 $\mathrm{g}$ for Tunisian cumin seeds and $88 \mathrm{mg}$ $\mathrm{QE} / 100 \mathrm{~g}$ for Indian cumin seeds. Our amount was significantly higher than that showed by Munuswamy and Ramachandiran [17] (15.1 mg QE/100 g). However, other researchers, Zhang et al. [52, 53, 63] found higher contents: $102 \mathrm{mg} \mathrm{QE} / 100 \mathrm{~g}, 560 \mathrm{mg}$ $\mathrm{QE} / 100 \mathrm{~g}$ and $4656 \mathrm{mg} \mathrm{QE} / 100 \mathrm{~g}$, respectively.

The significant differences between plants $(p=0.000)$ in the terms of flavonoids were explained by several factors such as genotypic and environmental differences within species [64], choice of parts tested [65], time of taking samples [66] and determination methods [67].

The presence of condensed tannins in fenugreek agrees with the results of Abdouli et al. [35, 46, 68] with significant differences: $2.3 \mathrm{mg} \mathrm{CE} / 100 \mathrm{~g}, 0.29 \mathrm{mg}$ $\mathrm{CE} / 100 \mathrm{~g}$, and $0.78 \mathrm{mg} \mathrm{CE} / 100 \mathrm{~g}$, respectively.

Rahmani et al. [61] found higher value (73 $\pm 0.013-105.1 \pm 0.030 \mathrm{mg} \mathrm{CE} / 100 \mathrm{mg}$ ), although, Benziane et al. [49] observed that fenugreek aqueous extract showed a highest amount of condensed tannins: $8.69 \mathrm{mg} \mathrm{CE} / 100 \mathrm{~g}$. The levels of present results were lower than that reported in Iranian fenugreek seed genotype (380 mg CE/100 g DM) [69] and hugely lower than that reported in Yemen genotype (2000 mg CE/100 g) [62]. Levels measured in fenugreek seeds were far below threshold level (5000 mg CE/100 g DM) mentioned by Muller-Harvey [70]. Besides, a lower condensed tannins content was recorded in cumin, in comparison with fenugreek. The present result was lower than results of Rebey et al. [51, 54] (200 mg CE/100 g, $4228 \mathrm{mg}$ $\mathrm{CE} / 100 \mathrm{~g}$ ), and extremely lower than that of Rebey et al. [53] with an amount of $6571 \mathrm{mg} \mathrm{CE} / 100 \mathrm{~g}$ for Tunisian cumin seeds and $6137 \mathrm{mg}$ CE/100 g for Indian cumin seeds. Cumin is known to contain large amount of tannins [71].

The difference in findings $(p=0.000)$ may be due to extraction methods and solvents used [72], cultivar type, growing conditions, maturity stage at harvest, storage conditions and sample preparation method [47]. In contrary to hydrolysable tannins contents, there is no substantial difference between these two plants.

Results of the phytochemical screening of methanolic extracts of fenugreek did not exclusively agree with the report of Asmena et al. [73] which shows the absence of flavonoids, tannins and cardiac glycosides, even the presence of alkaloids steroids and carbohydrate. However, Sumayya et al. [3] assent with our study, and found many secondary metabolites in fenugreek extract like flavonoids, tannins, phenols, carbohydrate, glycosides, anthocyanin and terpenoids. Further Rodolfo et al. [74, 75] studies showed the presence of flavonoids, steroids, alkaloides, and saponins in fenugreek extract. Gorinstein et al. [76], also reported the presence of terpenoids, tannins and absence of anthocyanin.

A recent study of Megha et al. [37] concerning the qualitative analysis of cumin registered a moderate presence of alkaloids, flavonoids, steroids, carbohydrate, phenol and terpenoids, whereas tannins, saponins, protein, glycosides and cardiac glycosides were reported to be absent in this plant extract. Furthermore, Himanshu et al. [77] reported the richness of cumin extract with alkaloids, glycosides, flavonoids, tannins, terpenoids and phenolic compounds which are in the contrary to our results.

Qualitative and quantitative analysis of important individual phenolics in the spices may help reveal the structure-activity relationships of antioxidant phenolics and to explain the relationships between total antioxidant activity and total phenolic contents [50].

In the C. cyminum extract, the separation of flavonoids at retention times between 10 and $20 \mathrm{~min}$. 
is observed, which are not derived from quercetin, having absorption maxima between 330 and $345 \mathrm{~nm}$. At 20.030 minute, a polyphenol appears, that seems to be of the tannin class, probably a complex or condensed tannin. Tannins also appear at $4.864 \mathrm{~min}$. and $7.881 \mathrm{~min}$., respectively. At retention times higher than $20 \mathrm{~min}$., polyphenols appear; that seems to be of the coumarin class.

C. cyminum extract appears to be the richest in polyphenols. Among the flavonoids, those from $14.322 \mathrm{~min}$. and $12.280 \mathrm{~min}$., respectively, are the majority, representing $30.5 \%$ and $20.8 \%$, respectively, of total of the most important polyphenols. Others are under $11 \%$.

In the case of $T$. foenum-graecum extract at $3.115 \mathrm{~min}$. a tannin is separated, probably a gallic acid derivative, then at minutes $7.577,10.146,10.657$ and 11.957 flavonoids with maximum absorption between 330 and $340 \mathrm{~nm}$, and at over 15 minutes polyphenols that seems to be from coumarin class. At minute 9.838 , a polyphenol with a spectrum specific to caffeic acid derivatives appears.

Among the majority of flavonoids, the predominant quantity is the one from minute 10.657 , this being in proportion of $47.3 \%$, and the component separated at $11.957 \mathrm{~min}$. in proportion of $26.9 \%$.

Previous study about the characterization of secondary metabolites in cumin observed the presence of coumaric acid, luteolin, syringic acid, cinnamic acid for Tunisian cumin seeds and trans2-dihydrocinnamic acid as well as flavone for Indian cumin seeds [51]. Eventually, Rebey et al. [53] found that phytochemical characterization of cumin revealed the presence of eighteen phenolic compounds, including gallic acid, caffeic acid, dihydroxyphenolic acid, dihydroxybenzoic acid, chlorogenic acid, syningic acid, vanillic acid, coumaric acid, ferrulic acid, rosmarinic acid, cinnamic acid, flavonoid, leutolin, catechin, coumarin, apigenin, amentoflavone and flavone. Also, Shan et al. [50] demonstrated that bioactive compounds present in cumin were phenolic acids, flavonoids, coumarins, caffeic acid, kaempferol and others compounds which were not determined. Ani et al. [78] could identify some phenolic compounds in cumin seeds such as gallic, caffeic, ellagic protocatechuic, ferulic acids and also flavonols, such as quercetin and kaempferol.

Concerning phenolic profile of fenugreek, some major components such as catechin, epicatechin, gallic acid, caffeic acid, coumaric acid, cinnamic acid, vanillic acid were previously found in fenugreek ethanolic extract [36] and others: gallic acid, chlorogenic acid, $p$-coumeric acid, ferulic acid, sinapic acid and quercetin in the methanolic extract [79].

Four phytochemical compounds were found in fenugreek aqueous maceration extract, namely: genistein, kaempferol, vanillin and myrecitin, while three compounds were identified in aqueous decoction extract, namely: kaempferol, rutin, and vanillin [49].

Also Swati et al. [80] exhibit that characterization of phenolic compounds present in fenugreek extract by HPLC could identify seven contents: vitexin, isovitexin, kaempferol dirhamnoside, kaempferol rhamnoside, quercitin, leuteolin and apigenin. In other research it was observed that flavonoid glycosides and kaempferol were two major phenolic compounds found in the aqueous extract of fenugreek [81].

The significant difference in the phenolic profile obtained by HPLC between fenugreek and cumin confirmed previous data of total phenolic and flavonoid contents. These differences could be related to many factors, such as genotype, stage of maturity, growing and climate conditions, harvest time and even post-harvest conditions [82]. Also, the results of chromatographic analysis using HPLC depend on the separating power of the column, the flow velocity and the composition of the mobile phase and column temperature [83].

Our study showed that free radical scavenging activity of cumin was lower than fenugreek. Regarding $\mathrm{IC}_{50}$, the lowest value was observed by fenugreek $(343.75 \pm 0.01 \mu \mathrm{g} / \mathrm{ml})$, followed by cumin $(588.55 \pm 0.01 \mu \mathrm{g} / \mathrm{ml})$. While, the results establish that fenugreek has more ability to scavenge the free radicals as compared to cumin.

Sakhira et al. [36] observed that fenugreek extract presents a similar $\mathrm{IC}_{50}$ to our result with a concentration of $285.59 \pm 2.01 \mu \mathrm{g} / \mathrm{ml}$ with higher radical scavenging activity, however, other researchers, such as Mashkor et al. [47] and Rababah et al. [48], present lower radical scavenging activities: $65-68 \%$ and $10 \%$, respectively. Regarding to cumin, previous study of Thippeswamy and Naidu [39] showed that radical scavenging activity of cumin was similar to our result: $\mathrm{IC}_{50} 520 \mu \mathrm{g} / \mathrm{ml}$, while others, such as Rebey et al. [51], present higher activities: $6.24 \mu \mathrm{g} / \mathrm{ml}$ for Tunisian cumin seeds and $15.14 \mu \mathrm{g} / \mathrm{ml}$ for Indian cumin seeds, Rebey et al. [53]: $20.17 \mu \mathrm{g} / \mathrm{ml}$ and Zhang et al. [52]: $102.42 \mu \mathrm{g} / \mathrm{ml}$. Aljuhaimi et al. studies $[55,84]$ gave a lower activities with $\mathrm{IC}_{50}$ : $825-1124 \mu \mathrm{g} / \mathrm{ml}$ and $2000 \mu \mathrm{g} / \mathrm{ml}$, respectively.

In addition, major differences in antioxidant activity between these two plants $(p=0.000)$ are primarily due to the difference in the polarity of the solvents 
used and therefore to the different effects of extractability on the antioxidant compounds $[85,86]$.

It is widely agreed that the antioxidant potential of phenolic compounds is often linked to the chemical composition of individual compounds, depending on a variety of factors, including geographical variation [87], harvest time [88], environmental and agronomic conditions [89], plant botanical components [90] and methods of extraction [91].

The literature presents ample evidence for the biological and biomedical activities of cumin, including its use as a treatment of a variety of diseases, such as chronic diarrhoea and dyspepsia, acute gastritis, diabetes, and cancer which have generally been ascribed to its bioactive constituents such as phenols and flavonoids [92]. Although, several animal studies and clinical data show that the use of fenugreek seeds can be useful in lowering cholesterol and blood glucose level. It has been found that compounds present in fenugreek extracts increase bile secretion and reduction in blood cholesterol, also administration of extracts from fenugreek seeds has a beneficial effect on blood glucose level, as it was confirmed by many studies performed in animals and in humans. It seems that such activity of compounds contained in fenugreek seeds is beneficial for people struggling with concomitant diseases in the metabolic syndrome [93]. In this context, the present study allowed to identify bioactive compounds which are economically important as drugs (pharmaceuticals) in medical field.

\section{CONCLUSION}

In our study, higher amounts of total phenolic compounds, flavonoids, condensed and hydrolysable tannins were found in fenugreek extract seeds.

Furthermore, the results of chromatographic analysis by HPLC revealed the presence of caffeic acid, isoquercetin, vanillic acid, myricetin 3-0-rutinoside, syringaresinol, citrusine, rosmarinic acid, and $p$-coumaric acid in cumin seeds and gallic acid, sinapic acid, caffeic acid, asterogenic acid, pyrogallol, hyperoside and ferulic acid in fenugreek seeds, this diversity could be explained by several factors such as genotype, stage of maturity, growing and climate conditions, harvest time and even post-harvest conditions.

It can be concluded that fenugreek extract possess a very strong antioxidant activity which showed an $\mathrm{IC}_{50}$ value of $343.75 \pm 0.01 \mu \mathrm{g} / \mathrm{ml}$ followed by cumin extract $(588.55 \pm 0.01 \mu \mathrm{g} / \mathrm{ml})$. This significant antioxidant potential may be due to polyphenolic constituents and flavonoids present in these two plants.

Therefore, fenugreek and cumin extracts seem to be a valuable source of natural antioxidants and may be applied commercially in pharmaceutical industry as drugs in the future.

Further scientific assessment of tested plant amalgams should be performed, including fractionation and further characterization of phytochemicals to identify the active components responsible for the biological activities, to determine the antioxidant effect of isolated molecules with maximum activity and to establish that the overall antioxidant effect is a measure of all the components present together and working together or their individual capacities.

\section{ACKNOWLEDGEMENTS}

The authors would like to sincerely thank the staff of Pharmaceutical Biochemistry and Clinical Laboratory, University of Medicine and Pharmacy, ClujNapoca, Romania for providing necessary facilities of characterization (HPLC). Also, the staff of Medicinal and Aromatic Plants Laboratory, Advanced Technology Application and Research Center, Kilis 7 Aralik University, Turkey for their contribution in phytochemical analysis, and Dr. Meliani Samia from Tiaret University, Algeria for statistical analysis.

Conflict of interest: Authors declare no conflict of interest.

\section{REFERENCES}

1. Gutteridge JM, Halliwell B. Free radicals and antioxidants. A historical look to the future. Ann NY Acad Sci 2000; 899:136-147. doi: http://dx.doi. org/10.1111/j.17496632.2000.tb06182.x

2. El-Ghorab A. Shibamoto T, Özcan M. Chemical composition and antioxidant activities of buds and leaves of capers (Capparis ovata Desf. var. canescens) cultivated in Turkey. J Essent Oil Res 2007; 19:72-77. doi: http://dx.doi.org/10.1080/10 412905.2007.9699233

3. Sumayya AR, Srinivasan S, Amatullah, N. Screening and biochemical quantification of phytochemicals in fenugreek (Trigonella foenumgraecum). Res J Pharm Biol Chem Sci 2012; 3:165-169. 
4. Al-Snafi AE. The pharmacological activities of Cuminum cyminum - A review. J Pharm 2016; 6(6):46-65.

5. Azeez S. Cumin. In: Parthasarathy VA, Chempakam B, Zachariah TJ (eds.). Chemistry of Spices. Oxfordshire 2008:445.

6. Dhandapani S, Subramanian VR, Rajagopal S, Namasivayam N. Hypolipidemic effect of Cuminum cyminum L. on alloxan-induced diabetic rats. Pharmacol Res 2002; 46: 251-225. doi: http:// dx.doi.org/10.1016/s1043-6618(02)00131-7

7. Romagnoli C, Andreotti E, Maietti S, Rai M, Mares D. Antifungal activity of essential oil from fruits of Indian Cuminum cyminum. Pharm Biol 2010; 48:834-838.

8. Iacobellis NS, Cantore PL, Capasso F, Senatore F. Antibacterial activity of Cuminum cyminum L. and Carum carvi L. essential oils. J Agric Food Chem 2005; 53:57-61. doi: http://dx.doi. org/10.1021/jf0487351

9. Jagtap A, Patil PB. Antihyperglycemic activity and inhibition of advanced glycation end product formation by Cuminum cyminum in streptozotocin induced diabetic rats. Food Chem Toxicol BIBRA. 2010; 48:2030-2036. doi: http://dx.doi. org/10.1016/j.fct.2010.04.048

10. Boskabady M, Kiani S, Azizi H. Relaxant effect of Cuminum cyminum on guinea pig tracheal chains and its possible mechanism (s). Indian J Pharmacol 2005; 37:111-115.

11. Aruna K, Rukkumani R, Varma PS, Menon VP. Therapeutic role of Cuminum cyminum on ethanol and thermally oxidized sunflower oil induced toxicity. Phytother Res 2005; 19:416-421. doi: http://dx.doi.org/10.1002/ptr.1596

12. Gagandeep, Dhanalakshmi S, Méndiz E, Rao AR, Kale RK. Chemopreventive effects of Cuminum cyminum in chemically induced forestomach and uterine cervix tumors in murine model systems. Nutr Cancer 2003; 47(2):171180. doi: http://dx.doi.org/10.1207/s15327914 nc4702_10

13. Janahmadi M, Niazi F, Danyali S, Kamalinejad M. Effects of the fruit essential oil of Cuminum cyminum Linn. (Apiaceae) on pentylenetetrazol-in- duced epileptiform activity in F1 neurones of Helix aspersa. J. Ethnopharmacol 2006; 104:278-282. doi: http://dx.doi.org/10.1016/j.jep.2005.09.019

14. Agrawala IP, Achar MV, Boradkar RV, Roy N. Galactagogue action of Cuminum cyminum and Nigella sativa. Indian J Med Res 1968; 56(6):841844.

15. Gupta RS, Saxena P, Gupta R, Kachhawa JB. Evaluation of reversible contraceptive activities of Cuminum cyminum in male albino rats. Contraception 2011; 84:98-107. doi: http://dx.doi. org/10.1016/j.contraception.2010.10.013

16. Koppula S, Choi D. Cuminum cyminum extract attenuates scopolamine-induced memory loss and stress-induced urinary biochemical changes in rats: A non-invasive biochemical approach. Pharm Biol 2011; 49:702-708. doi: http://dx.doi. org/10.3109/13880209.2010.541923

17. Munuswamy UR, Ramachandiran M. Comparative study on antioxidant potential and phytochemical composition of cumin and fennel. J Herb Med 2014;20(3):245-255. doi: http://dx.doi. org/10.1080/10496475.2013.861379

18. Altuntas E, Özgöz E, Taser O. Some physical properties of fenugreek (Trigonella foenum-graceum L.) seeds. J Food Eng 2005; 71: 37-43. doi: http://dx.doi.org/10.1016/j.jfoodeng.2004.10.015

19. Bahmani M, Shirzad H, Mirhosseini M, Mesripour A, Rafieian-Kopaei M. A review on ethnobotanical and therapeutic uses of fenugreek (Trigonella foenum-graceum L.). Evid Based Complement Altern Med 2016; 21:53-62. doi: http:// dx.doi.org/10.1177/2156587215583405

20. Basch E, Ulbricht C, Kuo G, Szapary P, Smith M. Therapeutic applications of fenugreek. Altern Med Rev Clin Ther 2003; 8:20-27.

21. Khosla P, Gupta DD, Nagpal RK. Effect of fenugreek on serum lipids in normal and diabetic rats. Int J Pharmacol 1995; 27:89-93.

22. Cowan MM. Plant products as antimicrobial agents. Clin Microbiol Rev1999; 12:564-582. doi: http://dx.doi.org/10.1128/cmr.12.4.564

23. Roberts KT, Allen-Vercoe E, Williams SA, Graham T, Cui SW. Comparative study of the in vitro 
fermentative characteristics of fenugreek gum, white bread and bread with fenugreek gum using human faecal microbes. Bioact Carbohydr Diet Fibre 2015; 5:116-124. doi: http://dx.doi. org/10.1016/j.bcdf.2014.09.007

24. Dixit P, Ghaskadbi S, Mohan H, Devasagayam T. Antioxidant properties of germinated fenugreek seeds. Phytother Res 2005; 19:977-983. doi: http://dx.doi.org/10.1002/ptr.1769

25. Bouhenni H, Doukani K, Sekeroglu N, Gezici S, Tabak S. Comparative study on chemical composition and antibacterial activity of fenugreek (Trigonella foenum-graecum L.) and cumin (Cuminum cyminum L.) seeds. Ukr Food J 2019; 8(4):755767. doi: http://dx.doi.org/10.24263/2304974x-2019-8-4-7

26. Gezici S, Sekeroglu N. Current perspectives in the application of medicinal plants against cancer: a novel therapeutic agents. Anti-Cancer Agent Med Chem 2019; 19(1):101-111. doi: http://dx.doi. org/10.2174/1871520619666181224121004

27. Singleton VL, Rossi J A. Colorimetry of total phenolics with phosphomolybdic phosphotungstic acid reagents. Am J Enol Vitic 1965; 16(3):144-158.

28. Zou Y, Lu Y, Wei D. Antioxidant activity of a flavonoid-rich extract of Hypericum perforatum L. in vitro. J Agr Food Chem 2004; 52:5032-5039. doi: http://dx.doi.org/10.1021/jf049571r

29. Price ML, Van Scoyoc S. A critical evaluation of the vanillin reaction as an assay for tannin in sorghum grain. J Agr Food Chem 1978; 26:12141218. doi: http://dx.doi.org/10.1021/jf60219a031

30. Mole S, Waterman P.G. A critical analysis of techniques for measuring tannins in ecological studies. Oecologia 1987; 72:137-147. doi: http:// dx.doi.org/10.1007/bf00385058

31. Trease GE, Evans WC, Pharmacognosy. 13th ed. London 1989:882-64.

32. Sofowora A. Medicinal plants and traditional medicine in Africa. Ibadan 1993:10-15.

33. Vlase L, Benedec D, Hanganu D, Damian G, Csillag I, Sevastre B, Tilea I. Evaluation of antioxidant and antimicrobial activities and phenolic profile for Hyssopus officinalis, Ocimum basilicum and Teucrium chamaedrys. Molecules. 2014; 19

(5):5490-5507. doi: http://dx.doi.org/10.3390/ molecules 19055490

34. Shimada K, Fujikawa K, Yahara K, Nakamura T. Antioxidative properties of xanthone on the auto oxidation of soybean in cylcodextrin emulsion. J Agr Food Chem 1992; 40:945-948. doi: https:// doi.org/10.1021/jf00018a005

35. Abdouli H, Missaoui H, Jellali S, Tibaoui G, Tayachi L. Comparison of two fenugreek seed genotypes: bitterness value, secondary metabolites contents and biological activities. J New Sci 2014; 7:19-27.

36. Sakhria M, Hichem A, Hafsia B, Abdelfettah E, Najla H. Phytochemical study and protective effect of Trigonella foenum-graecum (Fenugreek seeds) against carbon tetrachloride-induced toxicity in liver and kidney of male rat. Biomed. Pharmacother 2016; 88:19-26. doi: http://dx.doi. org/10.1016/j.biopha.2016.12.078

37. Megha P, Swati J, Bharat M. Phytochemical screening and comparative study of antioxidant activity of Cuminum cyminum L. and Nigella sativa L. JSRR 2019; 8(2):1356-1364.

38. El-Ghorab AH, Nauman M, Anjum FM, Hussain S, Nadeem M. A comparative study on chemical composition and antioxidant activity of ginger (Zingiber officinale) and cumin (Cuminum cyminum). J Agric Food Chem 2010; 58(14):82318237. doi: http://dx.doi.org/10.1021/jf101202x

39. Thippeswamy NB, Naidu A. Antioxidant potency of cumin varieties - cumin, black cumin and bitter cumin - on antioxidant systems. Eur Food Res Technol 2005; 220:472-476.doi: http://dx.doi. org/10.1007/s00217-004-1087-y

40. Stalikas D. Extraction, separation, and detection methods for phenolic acids and flavonoids. J Sep Sci 2007. 30 (18):3268-3295. doi: http://dx.doi. org/10.1002/jssc.200700261

41. Do QD, Angkawijaya AE, Tran-Nguyen PL, HuongHuynh L, EdiSoetaredjo F, Ismadji S, YiHsu J. Effect of extraction solvent on total phenol content, total flavonoid content, and antioxidant activity of Limnophila aromatica. J Food Drug Anal 2014; 22(3):296-302. doi: http://dx.doi. org/10.1016/j.jfda.2013.11.001 
42. Silva CPD, Sousa MSB, Siguemoto ÉS, Soares RAM, Arêas JAG. Chemical composition and antioxidant activity of jatobá-do-cerrado ( $\mathrm{Hy}$ menaea stigonocarpa Mart.) flour. Food Sci Technol 2014; 34(3):597-603. doi: http://dx.doi. org/10.1590/1678-457x.6405

43. Naima R, Oumam MM, Hannache H, Sesbou A, Charrier B, Pizzi AP, Charrier-El Bouhtoury F. Comparison of the impact of different extraction methods on polyphenols yields and tannins extracted from Moroccan Acacia mollisima barks. Ind Crops Prod 2015; 70:245-252. doi: http:// dx.doi.org/10.1016/j.indcrop.2015.03.016

44. Felhi S, Daoud A, Hajlaoui H, Mnafgui K, Gharsallah N, Kadri A. Solvent extraction effects on phytochemical constituents profiles, antioxidant and antimicrobial activities and functional group analysis of Ecballium elaterium seeds and peels fruits. Food Sci Technol Int 2017; 37(3):483-492. doi: http://dx.doi.org/10.1590/1678-457x.23516

45. Kaviarasan S, Vijayalakshmi K, Anuradha C. Polyphenol-rich extract of fenugreek seeds protect erythrocytes from oxidative damage. Plant Foods Hum Nutr 2004; 4:143-147. doi: https:// doi.org/10.1007/s11130-004-0025-2

46. Abdouli H, Hadj Ayed M, Elham M, Nabila B, Remedios Alvir Morencos M. Proximate composition, and total phenols, tannins, flavonoids and saponins, and in vitro ruminal fermentation activity of fenugreek cut at three maturity stages. Livest Res Rural Dev 2012; 24(1).

47. Mashkor IM. Phenolic content and antioxidant activity of fenugreek seeds extract. Int J Pharmacogn Phytochem Res 2014; 6:841-844.

48. Rababah T, Hettiarachchy N, Horax R. Total phenolics and antioxidant activities of fenugreek, green tea, black tea, grape seed, ginger, rosemary, gotu kola, and ginkgo extracts, vitamin $\mathrm{E}$, and tert-butylhydroquinone. J Agr Food Chem 2004; 52:5183-5186. doi: http://dx.doi.org/10.1021/ jf049645z

49. Benziane MNA, Acem K, Aggad H, Abdali M. Phytochemistry, HPLC profile and antioxidant activity of aqueous extracts of fenugreek (Trigonella foenum-graecum L.) seeds grown in arid zones of Algeria. ASN 2019; 6(2):71-87. doi: https://doi.org/10.2478/asn-2019-0020
50. Shan B, Cai YZ, Sun M, Corke H. Antioxidant capacity of 26 spice extracts and characterization of their phenolic constituents. J Agric Food Chem 2005; 53:7749-7759. doi: http://dx.doi. org/10.1021/jf051513y

51. Rebey BI, Bourgou S, Sriti J, Msaada K, Limam F, Marzouk B. Essential oils and fatty acids composition of Tunisian and Indian cumin (Cuminum cyminum L.) seeds: A comparative study. J Sci Food Agric 2011; 91(11):2100-2107. doi: http:// dx.doi.org/10.1002/jsfa.4513

52. Zhang L, Feng S, Xu J. Profile of phytochemicals and antioxidant activities of different solvent extracts of cumin seeds. Appl Mech Mater 2014; 675-677. doi: https://doi.org/10.4028/www.scientific.net/amm.675-677.1612

53. Rebey BI, Bourgou S, Benslimene Debez I, Jabri Karoui I, Sellami Hamrouni I, Msaada K, Limam F, Marzouk B. Effects of extraction solvents and provenances on phenolic contents and antioxidant activities of cumin (Cuminum cyminum L.) seeds. Food Bioprocess Tech 2012; 5:2827-2836. doi: https://doi.org/10.1007/s11947-011-0625-4

54. Rebey BI, Bourgou S, Aidi Wannes W, Hamrouni I, Limam F, Marzouk B. Essential oils, phenolics, and antioxidant activities of different parts of cumin (Cuminum cyminum L.). J Agric Food Chem 2010; 58(19):10410-10418. doi: http:// dx.doi.org/10.1021/jf102248j

55. Al Juhaimi F, Ghafoor K. Extraction optimization and in vitro antioxidant properties of phenolic compounds from cumin (Cuminum cyminum L.) seed. Int Food Res J 2013; 20:1669-1675.

56. Lawrence BM. Progress in essential oils: tansy oil. Perfum Flav 2000; 25:33-47.

57. Koenen EV. Medicinal poisonous and edible plant in Namibia. $9^{\text {th }}$ ed. Berlin 2001.

58. Parida AK, Das AB, Sanada Y, Mohanty P. Effects of salinity on biochemical components of the mangrove, Aeceras corniculatum. Aquat Bot 2004; 80:77-87. doi: http://dx.doi.org/10.1016/j. aquabot.2004.07.005

59. Gálvez M, Martín-Cordero C, Houghton PJ, Ayuso MJ. Antioxidant activity of methanol extracts obtained from Plantago species. J Agric Food 
Chem 2005; 53(6):1927-1933. doi: http://dx.doi. org/10.1021/jf048076s

60. Bukhari S, Bhanger Md, Memon S. Antioxidative activity of extracts from fenugreek seeds (Trigonella foenum-graecum). Pak J Anal Environ Chem 2008; 9:78-83.

61. Rahmani M, Hamel L, Toumi-Benali F, Dif M M, Moumen F, Rahmani H. Determination of antioxidant activity, phenolic quantification of four varieties of fenugreek Trigonella foenum-graecum L. seed extract cultured in West Algeria. J Mater Environ Sci 2018; 9(6):1656-1661. doi: https:// doi.org/10.26872/jmes.2018.9.6.184

62. Yaser Al, Muneer A, Abdelhafid B, Daoudi C, Lazoni A. Chemical and phytochemical analysis of some antidiabetic plants in Yemen. Int Res J Pharm 2013; 2:72-76. doi: http://dx.doi. org/10.7897/2230-8407.04915

63. Gupta D. Comparative analysis of spices for their phenolic content, flavonoid content and antioxidant capacity. AIJRFANS 2013; 4:38-42.

64. Srinivasan K, Kaul CL, Ramarao P. Partial protective effect of rutin on multiple low dose streptozotocin-induced diabetes in mice. Indian J Pharmacol 2005; 37:327-328. doi: http://dx.doi. org/10.4103/0253-7613.16859

65. Kumar A, Kassavetis GA, Geiduschek EP, Hambalko M, Brent CJ. Functional dissection of the B component of RNA polymerase III transcription factor IIIB: a scaffolding protein with multiple roles in assembly and initiation of transcription. Mol Cell Biol 1997;17(4):1868-1880. doi: http:// dx.doi.org/10.1128/mcb.17.4.1868

66. Gao X, Björk L, Trajkovski V, Uggla M. Evaluation of antioxidant activities of rosehip ethanol extracts in different test systems. J Sci Food Agric 2000; 80:2021-2027. doi: https://doi.or g/10.1002/10970010(200011)80:14<2021::aid jsfa745>3.0.co;2-2

67. Pizzale L, Bortolomeazzi R, Vichi S, Überegger E, Conte L. Antioxidant activity of sage (Salvia officinalis and Salvia fruticosa) and oregano (Origanum onites and Origanum indercedens) extracts related to their phenolic compound content. J Sci Food Agric 2002; 82:1645-1651. doi: https://doi. org/10.1002/jsfa. 1240
68. Al-Maamari I, Khan M, Ali A, Al-Sadi A, Waly M, Al-Saady N. Diversity in phytochemical composition of omani fenugreek (Trigonella foenum - graecum L.) accessions. Pak J Agric Sci 2016; 53(4):1-12. doi: http://dx.doi.org/10.21162/pakjas/16.5559

69. Naseri V, Hozhabri F, Kafilzadeh F. Assessment of in vitro digestibility and fermentation parameters of alfalfa hay-based diet following direct incorporation of fenugreek seed (Trigonella foenum) and asparagus root (Asparagus officinalis). J Anim Physiol Anim Nutr 2012; 97(4):773-784. doi: https://doi.org/10.1111/j.1439-0396.2012.01318.x

70. Muller-Harvey I. Unraveling the conundrum of tannins in animal nutrition and health. J Anim Sci Food Agr 2006; 86:2010-2037. doi: https:// doi.org/10.1002/jsfa.2577

71. Uma Pradeep K, Geervani P, Eggum B O. Common Indian spices: Nutrient composition, consumption and contribution to dietary value. Plant Foods Hum Nutr 1993; 44:137-148. doi: https:// doi.org/10.1007/bf01088378

72. Uma DB, Ho CW, Wan AWM. Optimization of extraction parameters of total phenolic compounds for Henna (Lawsonia inermis) leaves. Sains Malaysiana 2010; 39:119-128.

73. Asmena M, Alauddin M, Rahman MA, Ahmed K. Antihyperglycemic effect of Trigonella foenumgraecum (fenugreek) seed extract in alloxan-induced diabetic rats and its use in diabetes mellitus: a brief qualitative phytochemical and acute toxicity test on the extract. Afr J Tradit Complement Altern Med 2009; 6(3):255-261. doi: http:// dx.doi.org/10.4314/ajtcam.v6i3.57165

74. Rodolfo J, Koroch A, Simon J, Hitiamana N. Quality of geranium oils: case studies in southern and eastern Africa. J Essent Oil Res 2006;18:116121. doi: https://doi.org/10.1080/10412905.2006. 12067131

75. Rahmani M, Toumi-Benali F, Hamel L, Dif MM. Aperçu ethnobotanique et phytopharmacologique sur Trigonella foenum-graecum L. Phytothérapie 2015. [in French] doi: https://doi. org/10.1007/s10298-015-0964-9

76. Gorinstein S, Park Y, Heo B, Namieśnik J, Kruszewska $\mathrm{H}$, Leontowicz $\mathrm{M}$, et al. A comparative study of phenolic compounds and anti- 
oxidant and antiproliferative activities in frequently consumed raw vegetables. Eur Food Res Technol 2009; 228:903-911. doi: http://dx.doi. org/10.1007/s00217-008-1003-y

77. Himanshu S, Saroj S, Sarada S, Rakesh S, Mohan K. Anti-diarrhoeal investigation from aqueous extract of Cuminum cyminum Linn. seed in albino rats. Pharmacognosy Research. 2014; 6:204-209. doi: http://dx.doi.org/10.4103/09748490.132596

78. Ani V, Varadaraj M, Naidu A. Antioxidant and antibacterial activities of polyphenolic compounds from bitter cumin (Cuminum nigrum L.). Eur. Food Res. Technol. 2006; 224:109-115. doi: http://dx.doi.org/10.1007/s00217-006-0295-Z

79. Pasha I, Shabbir M, Asim H M A, Afzal B, Chughtai MF, Ahmad S, Muhammad MS. Biochemical evaluation of Trigonella foenum-graecum (fenugreek) with special reference to phenolic acids. Pakistan Journal of Scientific and Industrial Research Series B: Biol Sci 2017; 60:154-16.

80. Swati D, Pradeep S, Jyoti R, Renu T, Arti B. phytochemical analysis of seeds of certain medicinal plants. Int Res J Pharm 2014; 5:102-105. doi: http://dx.doi.org/10.7897/2230-8407.050221

81. Benayad Z, Gómez-Cordovés C, Es-Safi NE. Characterization of flavonoid glycosides from fenugreek (Trigonella foenum-graecum) crude seeds by HPLC-DAD-ESI/MS analysis. Int J Mol Sci 2014; 15(11):20668-20685. doi: http://dx.doi. org/10.3390/ijms151120668

82. Chun J, Lee J, Ye L, Exler J, Eitenmiller R. Tocopherol and tocotrienol content of raw and processed fruits and vegetables in the United States diet. J Food Compos Anal 2006; 19:196-204. doi: http:// dx.doi.org/10.3390/ijms17101745

83. Johnson R, Vitha MF. Chromatography selectivity triangle. J Chromatogr 2011; 4:559-560. doi: http://dx.doi.org/10.1016/j.chroma.2010.09.046

84. Hinneburg I, Dorman D, Hiltunen R. Antioxidant activities of extracts from selected herbs and spices. Food Chem 2006; 97:122-129. doi: http:// dx.doi.org/10.1016/j.foodchem.2005.03.028

85. Djeridane A, Yous M, Nadjemi B, Boutassouna D, Stocker P, Vidal N. Antioxidant activity of some Algerian medicinal plants extracts containing phenolic compounds. Food Chem 2006; 97:654-660. doi: http://dx.doi.org/10.1016/j. foodchem.2005.04.028

86. Maisuthisakul P, Suttajit M, Pongsawatmanit R. Assessment of phenolic content and free radicalscavenging capacity of some Thai indigenous plants. Food Chem 2007; 100:1409-1418. doi: http://dx.doi.org/10.1016/j.foodchem.2005.11.032

87. Xi W, Zhang Y, Sun Y, Shen Y, Ye X, Zhou Z. Phenolic composition of Chinese wild mandarin (Citrus reticulata Balnco.) pulps and their antioxidant properties. Ind Crops Prod 2014; 52:466-474. doi: https://doi.org/10.1016/j.indcrop.2013.11.016

88. Fang S, Yang W, Chu X, Shang X, She C, Fu X. Provenance and temporal variations in selected flavonoids in leaves of Cyclocarya paliurus. Food Chem 2011;124:1382-1386. doi: http://dx.doi. org/10.1016/j.foodchem.2010.07.095

89. Liu Y, Qian C, Ding S, Shang X, Yang W, Fang $S$. Effect of light regime and provenance on leaf characteristics, growth and flavonoid accumulation in Cyclocarya paliurus (Batal) Iljinskaja coppices. Bot Stud 2016; 57(28):1-13. doi: http:// dx.doi.org/10.1186/s40529-016-0145-7

90. Bessada S M, Barreira JC, Barros L, Ferreira IC, Oliveira MBP. Phenolic profile and antioxidant activity of Coleostephus myconis (L.) An underexploited and highly disseminated species. Ind Crops Prod 2016; 89:45-51. doi: http://dx.doi. org/10.1016/j.indcrop.2016.04.065

91. Kurihara H, Asami S, Shibata H, Fukami H, Tanaka T. Hypolipemic effect of Cyclocarya paliurus (Batal) Iljinskaja in lipid-loaded mice. Biol Pharm Bull 2003; 26:383-385. doi: http://dx.doi. org/10.1248/bpb.26.383

92. Mnif S, Aifa S. Cumin (Cuminum cyminum L.) from traditional uses to potential biomedical applications. Chem Biodivers 2015; 12(5):733-742. doi: http://dx.doi.org/0.1002/cbdv.201400305.

93. Kassaian N, Azadbakht L, Forghani B, Amini M. Effect of fenugreek seeds on blood glucose and lipid profiles in type 2 diabetic patients. Int J Vitam Nutr Res 2009; 79(1):34-39. doi: http:// dx.doi.org/10.1024/0300-9831.79.1.34 